\title{
Hydrogen peroxide-independent generation of superoxide by plant peroxidase: hypotheses and supportive data employing ferrous ion as a model stimulus
}

\section{Makoto Kimura, Yosuke Umemoto and Tomonori Kawano*}

Laboratory of Chemical Biology and Bioengineering, Graduate School and Faculty of Environmental Engineering, The University of Kitakyushu, Kitakyushu, Japan

Edited by:

Antoine Danon, Institut de Biologie

Physico Chimique, France

\section{Reviewed by:}

Patrice Meimoun, Université Pierre et Marie Curie, France

Patrice Thuleau, Centre National de la Recherche Scientifique, France

${ }^{*}$ Correspondence:

Tomonori Kawano, University of

Kitakyushu, 1-1 Hibikino,

Wakamatsu-ku, Fukuoka,

Kitakyushu 808-0135, Japan

e-mail:kawanotom@kitakyu-u.ac.jp
When plants are threaten by microbial attacks or treated with elicitors, alkalization of extracellular space is often induced and thus $\mathrm{pH}$-dependent extracellular peroxidase-mediated oxidative burst reportedly takes place, especially at the site of microbial challenge. However, direct stimulus involved in activation of peroxidase-catalyzed oxidative burst has not been identified to date. Here, we would like to propose a likely role for free ferrous ion in reduction of ferric native peroxidase into ferrous enzyme intermediate which readily produces superoxide anion via mechanism involving Compound III, especially under alkaline condition, thus, possibly contributing to the plant defense mechanism. Through spectroscopic and chemiluminescence (CL) analyses of reactions catalyzed by horseradish peroxidase (HRP), the present study proposed that plant peroxidase-catalyzed production of superoxide anion can be stimulated in the absence of conventional peroxidase substrates but in the presence of free ferrous ion.

Keywords: alkalization, auxin, Compound III, oxidative burst, peroxidase, superoxide

\section{INTRODUCTION}

In plants, two major mechanisms leading to the production of reactive oxygen species (ROS) involving either NADPH oxidases or peroxidases (POXs) have been proposed (Yoshioka et al., 2008). Events of plant defense against pathogenic microorganisms, represented by plant cellular perception of microbial molecules contributing to so-called microbe-associated molecular patterns (MAMPs) such as bacterial flagellin, referred to as patterntriggered immunity, reportedly trigger a rapid and transient accumulation of ROS (O'Brien et al., 2012a). In Arabidopsis, molecular evidence for involvement of two identified cell wall POXs, namely, PRX33 and PRX34, in MAMPs-responsive apoplastic ROS generation has been reported (Bindschedler et al., 2006; O'Brien et al., 2012a,b).

In fact, plants are rich sources of enzymes involved in production and removal of ROS (Yoshioka et al., 2008). A Swiss group of POX research specialists metaphorically described that plant enzymes belonging to POXs (EC 1.11.1.7) display more functions than a "Swiss army knife" (Passardi et al., 2005). As suggested, highly diversified roles of plant POXs including regulation of hydrogen peroxide $\left(\mathrm{H}_{2} \mathrm{O}_{2}\right)$ level, oxidation of various substrates, generation of ROS coupled to oxidation of aromatic monoamines (AMAs) such as phenylethylamine (Kawano et al., 2000a,b) and phenolics such as salicylic acid (SA) (Kawano et al., 2004; Kawano and Bouteau, 2013) in living plants have been documented to date. By using a variety of electron $\left(\mathrm{e}^{-}\right)$-donating substrates and $\mathrm{H}_{2} \mathrm{O}_{2}$, the common $\mathrm{e}^{-}$acceptor, plant POXs achieve a great deal of oxidation reactions essential for the functions of living cells (Kawano, 2003a). Through production of certain POX isoforms at specific timing and localization, thus by properly and precisely making use of a variety of plant POX functions, the growing plants can respond to and combat a wide variety of stressful challenges with biotic or abiotic nature (Penel, 2000; Hiraga et al., 2001).

As intensively discussed in the plant research community, oxidation of phenolics is one of the key functions of POXs (Passardi et al., 2005). It is widely accepted that, in the presence of $\mathrm{H}_{2} \mathrm{O}_{2}$, plant POXs can catalyze the generation of superoxide anion radical $\left(\mathrm{O}_{2}^{\bullet-}\right)$ upon oxidation of substrates, chiefly phenolics (Kawano, 2003a; Yoshioka et al., 2008). Lower half of Figure 1A summarizes the mode of $\mathrm{O}_{2}^{--}$production via $\mathrm{e}^{-}$acceptordependently initiated conventional POX cycle enabling various substrates (AH) such as SA and AMAs. Apart from such $\mathrm{H}_{2} \mathrm{O}_{2}-$ requiring reaction, plant POXs are also capable of $\mathrm{O}_{2}^{\bullet-}$ generation via $\mathrm{e}^{-}$donor-dependently initiated and oxygen-requiring cycle involving few known substrates such as indole-3-acetic acid (IAA), the principal form of natural auxin in higher plants (Gazarian and Lagrimini, 1998; Savitsky et al., 1999; Kawano et al., 2001). Therefore, the $\mathrm{O}_{2}^{\bullet-}$-generating reactions catalyzed by plant POXs can be dissected into (i) the $\mathrm{H}_{2} \mathrm{O}_{2}$-dependent POX cycle and (ii) $\mathrm{H}_{2} \mathrm{O}_{2}$-independent oxygenation cycle as illustrated in Figure 1A. This model dissecting two distinct cycles initiated by interaction of native POX with $\mathrm{e}^{-}$acceptor or $\mathrm{e}^{-}$donor, is sometimes referred to as the hourglass model due to its shape (Kawano, 2003a; Takayama et al., 2012; Kawano and Bouteau, 2013).

We view here that the role of IAA in POX-catalyzed generation of $\mathrm{O}_{2}^{\bullet-}$ is one of effective $\mathrm{e}^{-}$donors converting native enzyme into ferrous intermediate in the oxygenation cycle (Figure 1A, upper half). Idea on the IAA-dependent reduction of native plant POX 


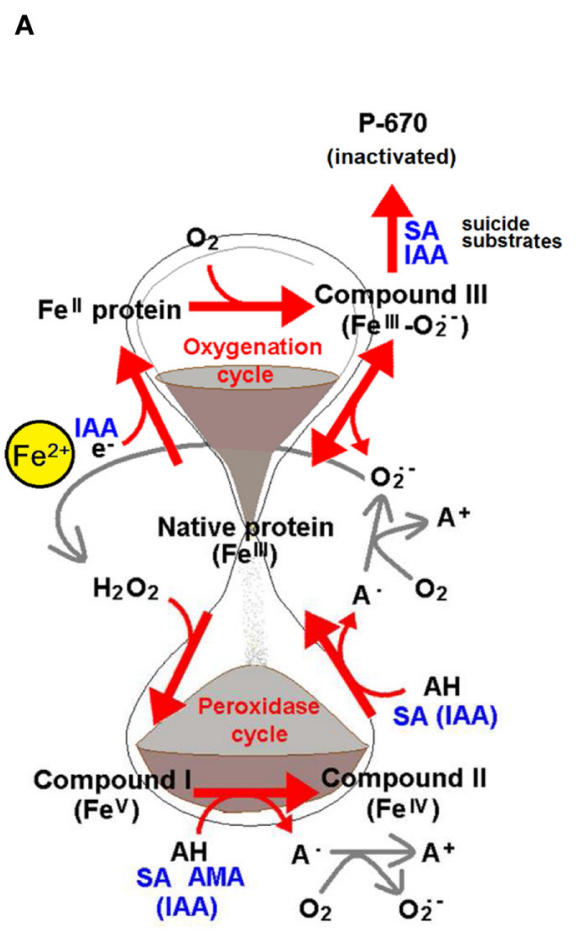

D

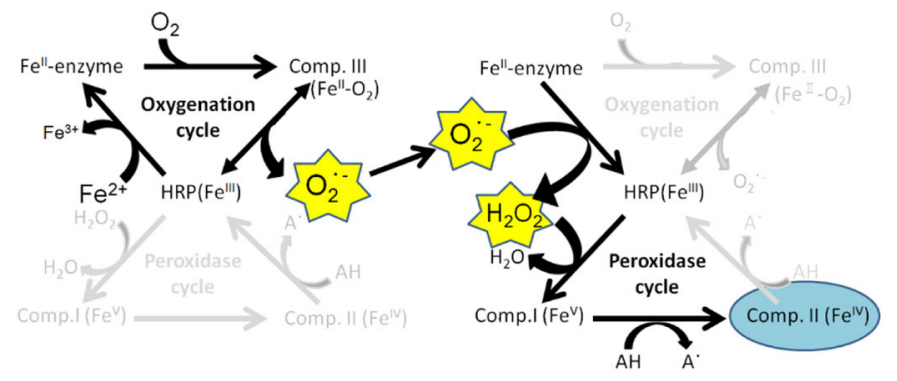

FIGURE 1 | Effects of key substrates for plant POXs on the inter-conversion of enzyme intermediates differed in redox-status. (A) Summary of known reactions involving IAA, SA, and AMAs leading to spectroscopic changes reflecting the presence of native ferric enzyme (absorption peaks at 403,500, and $639 \mathrm{~nm}$ ), ferrous enzyme (absorption maxima at 438 and $580 \mathrm{~nm}$ ), Compound I (absorption maxima at 577, 622, and $650 \mathrm{~nm}$ ), Compound II (absorption maxima at 420, 527, and $556 \mathrm{~nm}$ ) and Compound III (absorption maxima at 545 and $578 \mathrm{~nm}$ ). In this article, ferrous ion is proposed as the stimulus converting native enzyme to the ferrous enzyme complex. (B) Effect of $\mathrm{Fe}^{2+}$ on dissolved $\mathrm{O}_{2}$-dependent conversion of native HRP into Compound II. To the reaction mixture (final total volume, $400 \mu \mathrm{l}$; prior to Fe supplementation, $383 \mu \mathrm{l})$ contained K-phosphate $(25 \mathrm{mM}$,

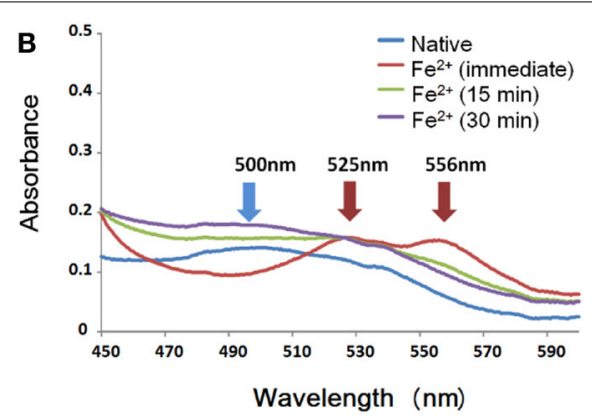

C

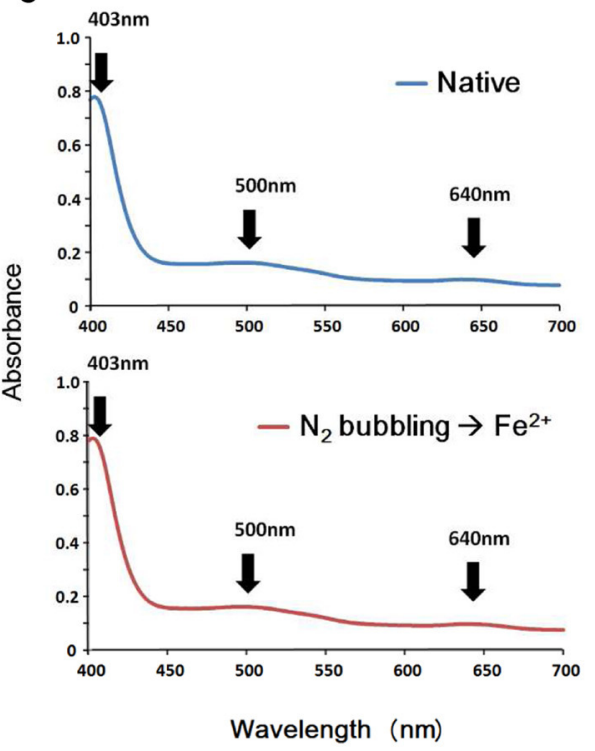

to ferrous enzyme intermediate has been proposed by Smith et al. (1982). The series of reactions triggered by IAA further proceeds under the atmospheric condition rich in $\mathrm{O}_{2}$, therefore, the ferrous complex might be short-lived and readily converted to $\mathrm{O}_{2}$-bound
$\mathrm{pH}$ 7.0), $\mathrm{HRP}(15 \mu \mathrm{M}), 17 \mu$ l of $5 \mathrm{mM} \mathrm{Fe}^{2+}$ (as $\mathrm{FeSO}_{4}$, final conc., $200 \mu \mathrm{M}$ ) was added. Then sample was spectroscopically scanned within $1 \mathrm{~min}$ (immediate) and at 15 and $30 \mathrm{~min}$ after addition of Fe. (C) Similarly to (B), to the reaction mixture (final total volume, $1 \mathrm{ml}$; prior to Fe supplementation, $940 \mu \mathrm{l}$ ) containing K-phosphate $(25 \mathrm{mM}, \mathrm{pH} 7.0)$ and $\operatorname{HRP}(15 \mu \mathrm{M})$ and presence of native enzyme was spectroscopically confirmed (top). To the above reaction mixture, $\mathrm{Fe}^{2+}$ was added $\left(40 \mu \mathrm{l}\right.$ of $5 \mathrm{mM} \mathrm{FeSO}_{4}$; final conc., $200 \mu \mathrm{M}$ ), but only after deoxygenation with $\mathrm{N}_{2}$ gas ( $\mathrm{N}_{2}$ bubbling) which was passed through using the syringe needle for $15 \mathrm{~s}$ (bottom). (D) The likely paths of $\mathrm{Fe}^{2+}$-induced conversion of native HRP to Compound II via of $\mathrm{O}_{2}^{\bullet-}$ generating steps followed by release of $\mathrm{H}_{2} \mathrm{O}_{2}$. Note that the $\mathrm{O}_{2}^{\bullet-}$-to- $\mathrm{H}_{2} \mathrm{O}_{2}$ conversion can proceed without enzyme at acidic condition and free $\mathrm{Fe}^{2+}$ may accelerate the processes. form of enzyme intermediate known as Compound III (CIII) in which the state of heme iron can be described as $\mathrm{O}_{2}$-heme-Fe $\mathrm{HI}^{\mathrm{II}}$ or $\mathrm{O}_{2}^{\bullet-}$-heme-Fe ${ }^{\mathrm{III}}$ (Kawano et al., 2002a). Then, gradual decay of this complex into native enzyme at heme-Fe ${ }^{\mathrm{III}}$ state accompanies 
the release of $\mathrm{O}_{2}^{\bullet-}$ (Figure 1A) as confirmed with IAA-stimulated horseradish peroxidase (HRP) using $\mathrm{O}_{2}^{\bullet-}$-specific chemiluminescence (CL) probe, Cypridina luciferin analog (CLA) (Kawano et al., 2001).

Assuming that the hypothetical model mechanism proposed in Figure 1A is correct, we should be able to screen or identify some effective $\mathrm{e}^{-}$donors from a variety of single $\mathrm{e}^{-}$reducing agents which target the native enzyme to trigger the onset of oxygenation cycle in plant POXs, eventually leading to a robust and long-lasting burst of $\mathrm{O}_{2}^{\bullet-}$ production. After testing a wide range of chemicals, we observed that free ferrous ion $\left(\mathrm{Fe}^{2+}\right)$ acts as a novel inducer of $\mathrm{O}_{2}^{\bullet-}$ production in aid of plant POX, possibly by behaving as an effective $\mathrm{e}^{-}$donor for $\mathrm{Fe}^{\mathrm{III}}$-to- $\mathrm{Fe}^{\mathrm{II}}$ conversion of heme in a model POX, HRP. The aim of the present article is to share our novel finding on the $\mathrm{Fe}$-driven $\mathrm{O}_{2}^{\bullet-}$ production mechanism involving HRP.

\section{MATERIALS AND METHODS CHEMICALS}

Purified HRP was purchased from Sigma (St. Louis, MO., USA), and used without further purification. CLA (2-methyl-6-phenyl3,7-dihydroimidazo[1,2-a]pyrazin-3-one), a chemiluminescent probe for $\mathrm{O}_{2}^{\bullet-}$, was purchased from Tokyo Kasei Kogyo Co. (Tokyo, Japan). Luminol, SA, IAA, metals, and other chemicals except for enzyme were purchased from Wako Pure Chemical Co. (Osaka, Japan). IAA (100 mM) was first dissolved in ethanol and diluted to the desired concentrations with heated water $\left(80^{\circ} \mathrm{C}\right)$. Then IAA solution was kept on ice in darkness until used. Final ethanol concentration in the reaction mixture was adjusted to be $0.1 \%(\mathrm{v} / \mathrm{v})$.

\section{SPECTROSCOPY}

Concentration of HRP was determined spectroscopically by measuring the concentration of heme $\left(\varepsilon 403 \mathrm{~nm}=102 \mathrm{mM} M^{-1} \cdot \mathrm{cm}^{-1}\right)$ (Gazaryan et al., 1996). Changes in absorption spectra of HRP in $20 \mathrm{mM} \mathrm{K}$-phosphate buffer ( $\mathrm{pH}$ 7.0) were recorded on spectrophotometer (Shimadzu UV-1800, Kyoto, Japan) at room temperature with a spectral bandwidth of $1.0 \mathrm{~nm}$ in a cuvette with 1-cm light path. Compounds II (CII) and CIII derived from native HRP $(7.5 \mu \mathrm{M})$ were determined spectroscopically.

\section{CHEMILUMINESCENCE (CL) ANALYSIS}

Generation of $\mathrm{H}_{2} \mathrm{O}_{2}$ and $\mathrm{O}_{2}^{\bullet-}$ in the HRP reaction mixture were monitored with $\mathrm{H}_{2} \mathrm{O}_{2}$-specific $\mathrm{CL}$ of luminol and $\mathrm{O}_{2}^{\bullet-}$-specific CL of CLA using a luminometer (Luminescensor PSN AB-2200R, Atto Corp., Tokyo, Japan) and expressed as relative luminescence units (rlu) as previously described for HRP-catalyzed generation of ROS (Kawano et al., 2001).

\section{RESULTS}

\section{PRELIMINARY SPECTROSCOPIC ANALYSES}

Basically, formation of CII from native ferric POX in the conventional peroxidase cycle requires the presence of $\mathrm{H}_{2} \mathrm{O}_{2}$, as we have previously observed that addition of excess $\mathrm{H}_{2} \mathrm{O}_{2}$ to HRP reaction mixture readily results in transient formation of Compound I (CI) followed by increase in CII without supplementation of any additional molecules known as POX substrate such as phenolics or amines (Kawano et al., 2002c,d). However, we observed that addition of $\mathrm{Fe}^{2+}$ to HRP resulted in accumulation of CII without addition of exogenous $\mathrm{H}_{2} \mathrm{O}_{2}$ (Figure 1B), suggesting that $\mathrm{H}_{2} \mathrm{O}_{2}$ is formed after a series of reactions involving redox changes in $\mathrm{POX} / \mathrm{Fe}^{2+}$ system. Interestingly, conversion of native HRP to CII by $\mathrm{Fe}^{2+}$ was completely inhibited by deoxygenating treatment such as bubbling with $\mathrm{N}_{2}$ gas (Figure 1C) and addition of sodium dithionite (data not shown), indicating the involvement of molecular oxygen at least at a certain step in the course of native-to-CI conversion.

\section{IRON-INDUCED GENERATION OF ROS}

As expected from the behavior of $\mathrm{Fe}^{2+}$ converting the native enzyme to CII, release of $\mathrm{H}_{2} \mathrm{O}_{2}$ could be detected in $\mathrm{Fe}^{2+}$-added $\mathrm{HRP}$ reaction mixture (Figure 2). Therefore, it is tempting to conclude that $\mathrm{Fe}^{2+}$-dependently produced $\mathrm{H}_{2} \mathrm{O}_{2}$ plays a key role in conversion of native enzyme to $\mathrm{CII}$ via transient formation of CI.

Similarly to the profile of $\mathrm{H}_{2} \mathrm{O}_{2}$, robust production of $\mathrm{O}_{2}^{\bullet-}$ was also observed after addition of $\mathrm{Fe}^{2+}$ to HRP (Figure 3). Note that the addition of $\mathrm{Fe}^{2+}$ resulted in biphasic increase in CLA$\mathrm{CL}$, consisting of an immediate short-lasting spike followed by secondary but intense and long-lasting peak depending on the concentration of $\mathrm{Fe}^{2+}$ added. As far as we understand, the initial spikes sized similar to the water control are kinds of artifacts

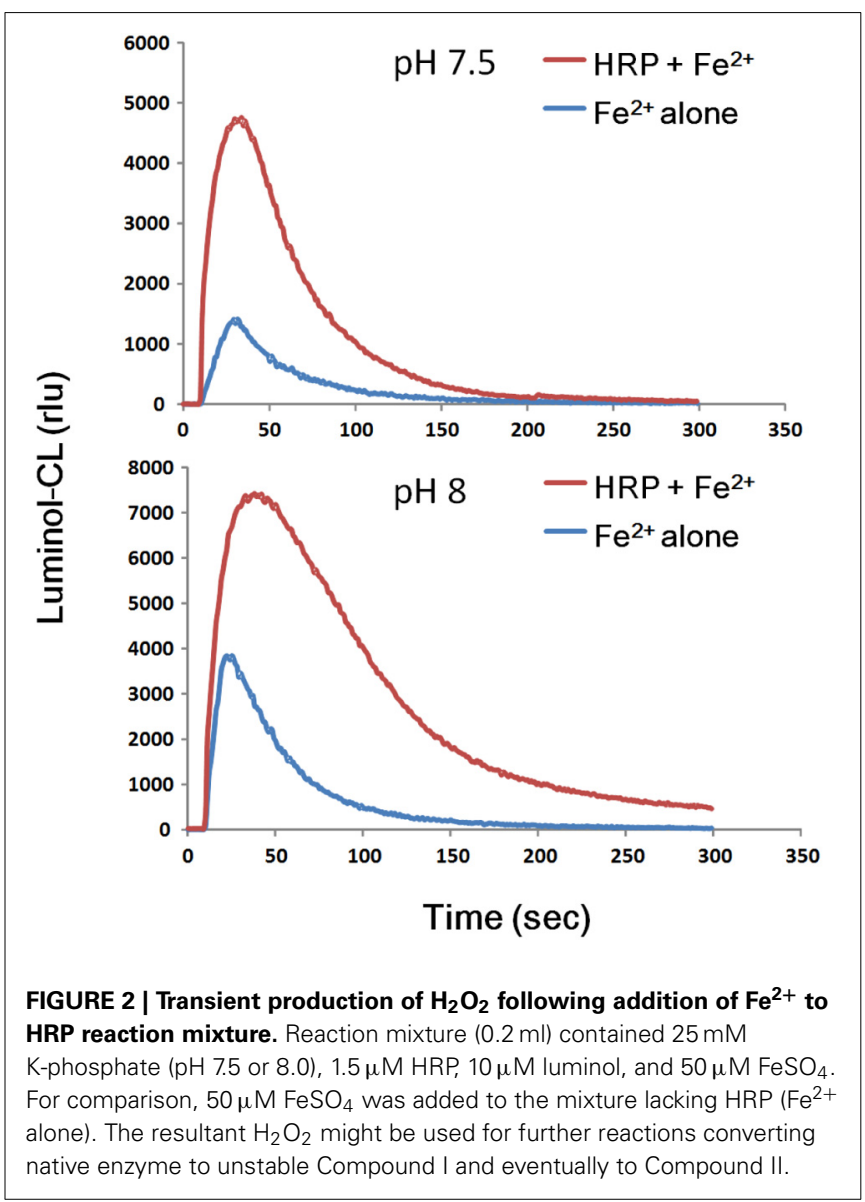




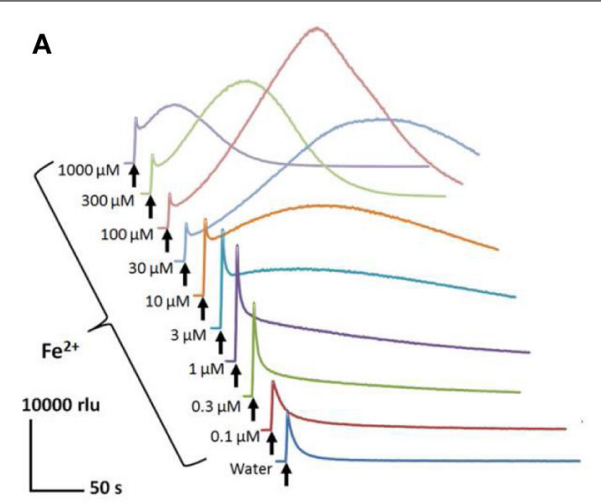

B
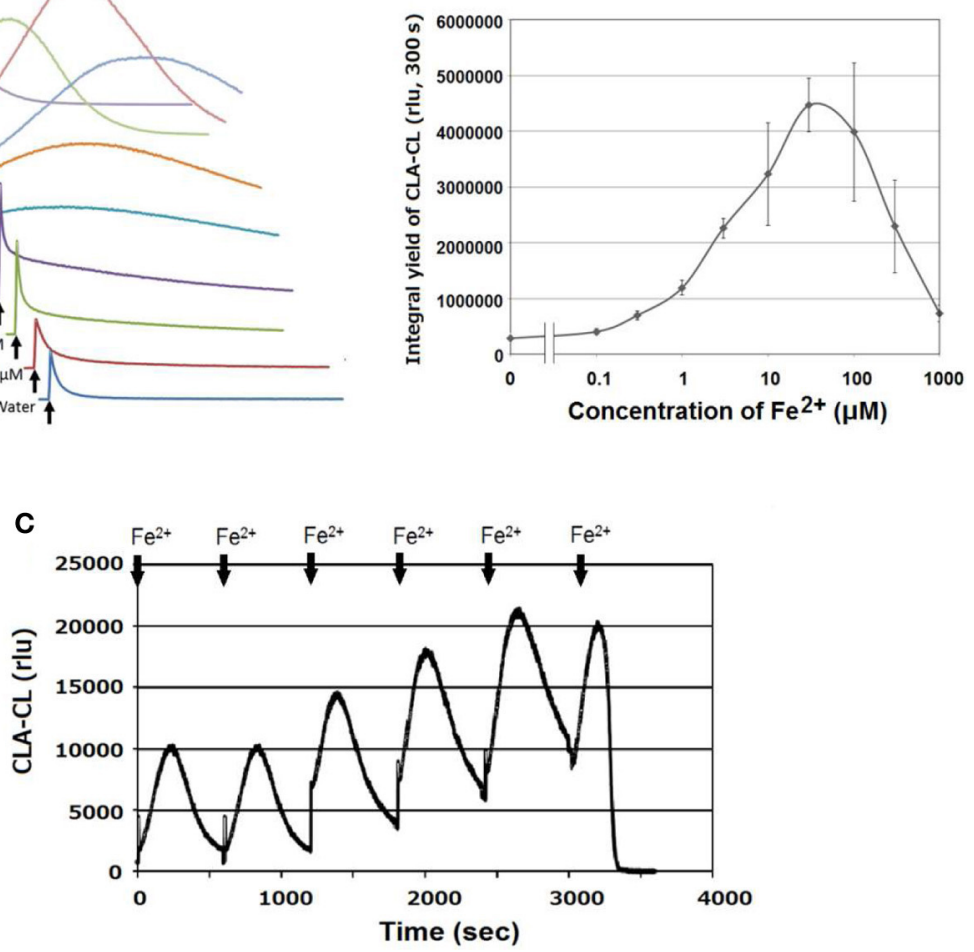

FIGURE 3 | $\mathrm{Fe}^{2+}$-induced $\mathrm{O}_{2}^{\bullet-}$ generation in $\mathrm{HRP}$ reaction mixture. (A) Temporal changes in $\mathrm{Fe}^{2+}$-induced $\mathrm{O}_{2}^{\bullet-}$-dependent CLA-CL. (B) Effect of $\mathrm{Fe}^{2+}$ concentrations (as indicated) on the yield of CLA-CL summed up within
$300 \mathrm{~s}$ after addition of $\mathrm{Fe}^{2+}$ or control water. Bars, $\mathrm{SD}(n=3)$. (C) Successive addition of $50 \mu \mathrm{M} \mathrm{Fe}^{2+}$ until CLA run out. Conditions: total volume, $0.2 \mathrm{ml}$; K-phosphate, $25 \mathrm{mM}$ (pH 7.0); HRP, $1.5 \mu \mathrm{M}$; CLA, $10 \mu \mathrm{M}$ (A,B), $40 \mu \mathrm{M}$ (C). by rapidly injecting the reagent or control water through a syringe which rapidly causes the mixing of media and air (containing oxygen). This type of spikes can be commonly observed for CLA-CL monitoring as described in our previous studies (Monetti et al., 2014). In fact, the increase higher than the level of water control could have been attributed to the action of Fe. Therefore, there would be two modes of oxidative burst induced by ferrous ion, one is rapidly induced by lower range of $\mathrm{Fe}^{2+}$ concentrations observed as the short-lasting increase in initial spike of CLA-CL, and another follows the initial spike, gradually attaining much higher peak level of CLA-CL by responding to relatively higher range of $\mathrm{Fe}^{2+}$ concentrations (Figure 3A).

Here, we emphasized the secondary peaks which last for more than some minutes. Interestingly, depending on the concentrations of $\mathrm{Fe}^{2+}$ added to HRP, both the extent and duration of oxidative burst largely varied. Furthermore, we observed that successive additions of $\mathrm{Fe}^{2+}$ (6 times an hour) repeatedly caused the burst of $\mathrm{O}_{2}^{\bullet-}$ by HRP until the CL probe was completely consumed (Figure 3C), suggesting that the enzyme has capacity for continuous and robust oxidative burst if reducing agents are continuously supplied.

As shown in Figure 4, both ferric and ferrous ions induce the generation of $\mathrm{O}_{2}^{\bullet-}$. However, the temporal profiles of ferric and ferrous-induced $\mathrm{O}_{2}^{\bullet-}$ generation largely differed, suggesting that the modes of $\mathrm{O}_{2}^{\bullet-}$ generation may also differ (at present, such difference is unknown). The $\mathrm{Fe}^{2+}$-induced $\mathrm{O}_{2}^{\bullet-}$ generation last for
5-10 min while the $\mathrm{Fe}^{3+}$ induces a short-lived spike of $\mathrm{O}_{2}^{\bullet-}$ generation only. By comparing the yield of CLA-CL (within $300 \mathrm{~s}$ ), the extent of $\mathrm{Fe}^{2+}$-induced $\mathrm{O}_{2}^{\bullet-}$ generation is at 5 -fold greater level compared to the $\mathrm{Fe}^{3+}$-induced one (Figure 4B). Addition of $\mathrm{Fe}^{2+} / \mathrm{Fe}^{3+}$ mixture induced a compromised pattern of CLACL (Figure 4A), with much higher yield of CLA-CL (Figure 4B). These data are indicative of the potential impact of free iron ions both at ferric and ferrous state may stimulate the oxidative burst mediated by plant POX although we focus mostly on the action of ferrous ion in the present study.

\section{INVOLVEMENT OF $\mathrm{O}_{2}$ IN Fe $\mathrm{F}^{2+}$-INDUCED HRP REACTION LEADING TO 0:- GENERATION}

As the involvement of dissolved oxygen was suggested by preliminary spectroscopic monitoring of $\mathrm{N}_{2}$-sensitive conversion of $\mathrm{Fe}^{2+}$-treated native enzyme into $\mathrm{CII}$, we examined the requirement for $\mathrm{O}_{2}$ in $\mathrm{Fe}^{2+}$-induced $\mathrm{HRP}$ reaction leading to $\mathrm{O}_{2}^{\bullet-}$ generation (Figure 5). The $\mathrm{Fe}^{2+}$-induced increase in CLA-CL was effectively lowered or delayed by removal of dissolved oxygen by $\mathrm{N}_{2}$ bubbling and inhibited by addition of sodium dithionite which is a convenient reagent that rapidly removes dissolved oxygen. As the air diffuses back into the reaction mixture even after replacement with $\mathrm{N}_{2}$ gas by bubbling, the state of inhibition due to the lack of $\mathrm{O}_{2}$ did not last long. On the other hand, chemically performed deoxygenation by $\mathrm{Na}$ dithionite resulted in clear-cut inhibition. 


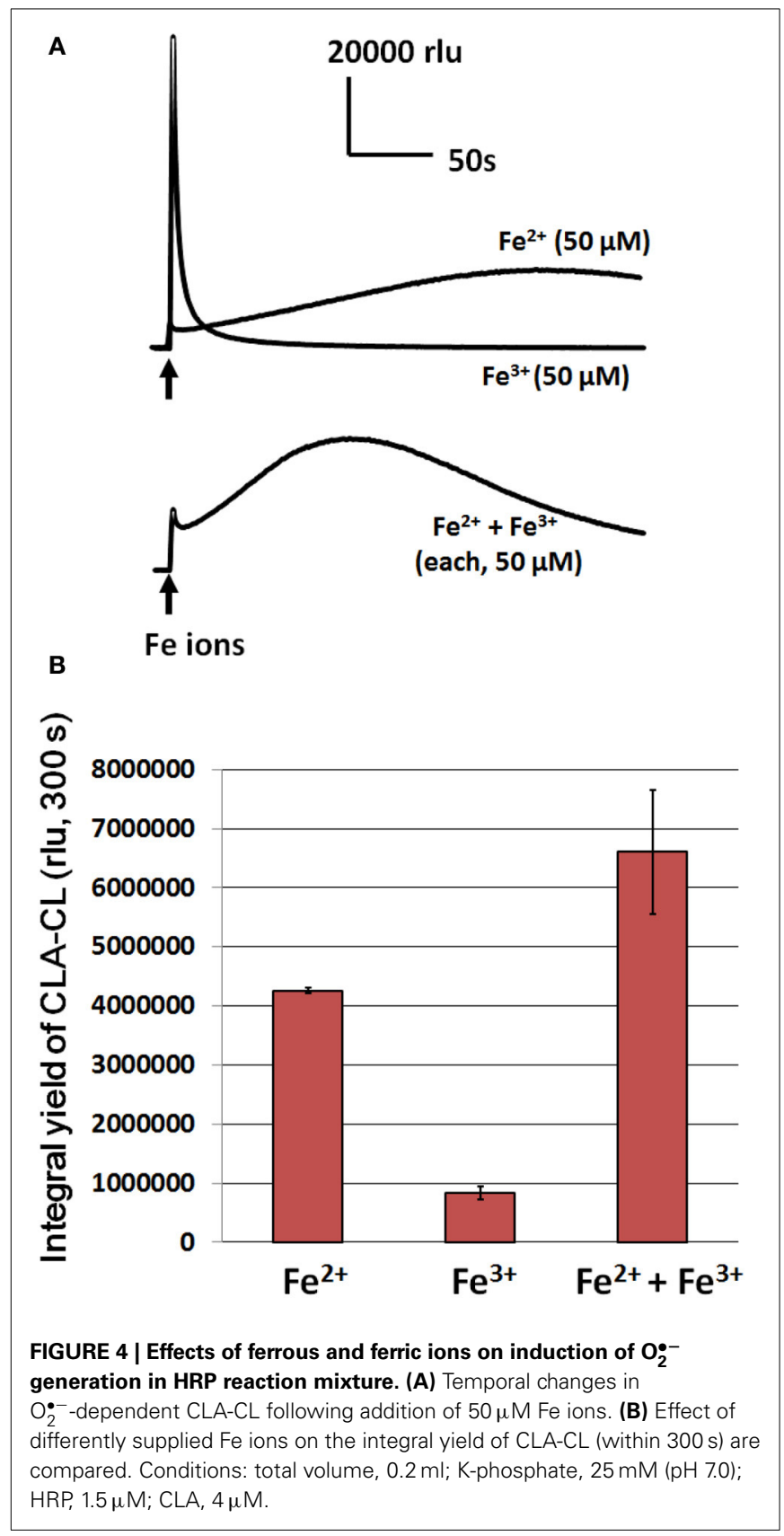

Above data are in support of our working hypothesis that, similarly to IAA-responsive mechanism, $\mathrm{Fe}^{2+}$-mediated conversion of native POX into ferrous enzyme intermediate further reacts with $\mathrm{O}_{2}$ to form catalytically inactive CIII which readily dissociates and releases $\mathrm{O}_{2}^{\bullet-}$ and native enzyme (Figure 1D).

\section{EFFECT OF pH ON HRP-CATALYZED OXIDATIVE BURST}

Effects of $\mathrm{Fe}^{2+}(50 \mu \mathrm{M})$ on induction of $\mathrm{O}_{2}^{\bullet-}$ generation was compared with two known inducers of POX-mediated oxidative burst, namely, SA and IAA (each $50 \mu \mathrm{M}$ ) under neutral and alkaline $\mathrm{pH}$ ( $\mathrm{pH} 7.0$ and 8.0; Figure 6). Among three $\mathrm{O}_{2}^{\bullet-}$ inducers, IAA was shown to be most active in induction of the spike of $\mathrm{O}_{2}^{\bullet-}$ while $\mathrm{Fe}^{2+}$ was the only chemical active in stimulation of a

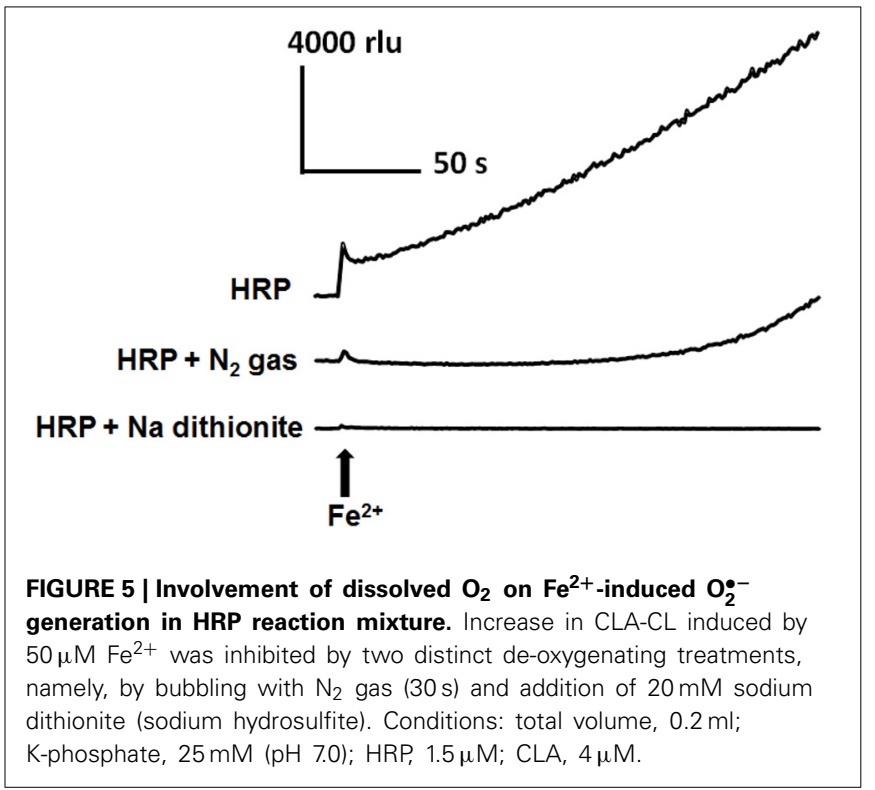

gradual and long-lasting mode of $\mathrm{O}_{2}^{\bullet-}$ production. As reported (Kawano and Muto, 2000; Takayama et al., 2012), SA-induced production of $\mathrm{O}_{2}^{\bullet-}$ was not impressive in the absence of initial $\mathrm{H}_{2} \mathrm{O}_{2}$ supplementation.

Despite of difference in the temporal profiles of induced $\mathrm{O}_{2}^{\bullet-}$ generation, the cumulative yields of $\mathrm{O}_{2}^{\bullet-}$ in response to $\mathrm{Fe}^{2+}, \mathrm{SA}$, and IAA under neutral condition ( $\mathrm{pH}$ 7.0) were at similar level (Figure 6C). It is noteworthy that the burst of $\mathrm{Fe}^{2+}$-stimulated $\mathrm{O}_{2}^{\bullet-}$ generation drastically increased under alkaline condition $(\mathrm{pH}$ 8.0) while SA and IAA showed no significant $\mathrm{pH}$ response (Figures 6B,C). Effect of $\mathrm{pH}$ on the $\mathrm{Fe}^{2+}$-induced $\mathrm{O}_{2}^{\bullet-}$ generation in HRP reaction mixture was further assessed by altering the medium $\mathrm{pH}$ between $\mathrm{pH} 4.26$ and 8.95 (Figure 7). In the alkaline range ( $\mathrm{pH}>7.0)$, the height of CLA-CL was shown to be drastically elevated. However, integral yield of CLA-CL was slightly lowered at highest $\mathrm{pH}$ examined as the pattern of $\mathrm{O}_{2}^{\bullet-}$ generation likely becomes spiky and less sustainable as $\mathrm{pH}$ elevated.

Above data suggested that $\mathrm{HRP}_{2} \mathrm{O}_{2}$-independently catalyzes the production of $\mathrm{O}_{2}^{\bullet-}$ from dissolve oxygen in the presence of ferrous ion. This model is distinct from the previously known mode of ROS production catalyzed by plant POXs. Therefore, in the below section, we wish to review and compare the likely mechanisms.

\section{DISCUSSION}

Interestingly, nitric oxygen (NO) is one of known agents that bind and convert the ferric form of hemoproteins such as nonsymbiotic hemoglobin from Arabidopsis (Perazzolli et al., 2004) into ferrous hemoproteins. In cases of plant POXs such as of soybean, the consequence of exposure of native POX to gaseous NO was accumulation of CII without exogenous supplementation of $\mathrm{H}_{2} \mathrm{O}_{2}$, suggesting that protein is once converted to ferrous form and eventually converted to and arrested as CII (Takayama et al., 2012). Among the known intermediates of POX and hemoproteins, the intermediate with ferrous heme is the only form with affinity to molecular oxygen; therefore, we should consider the 


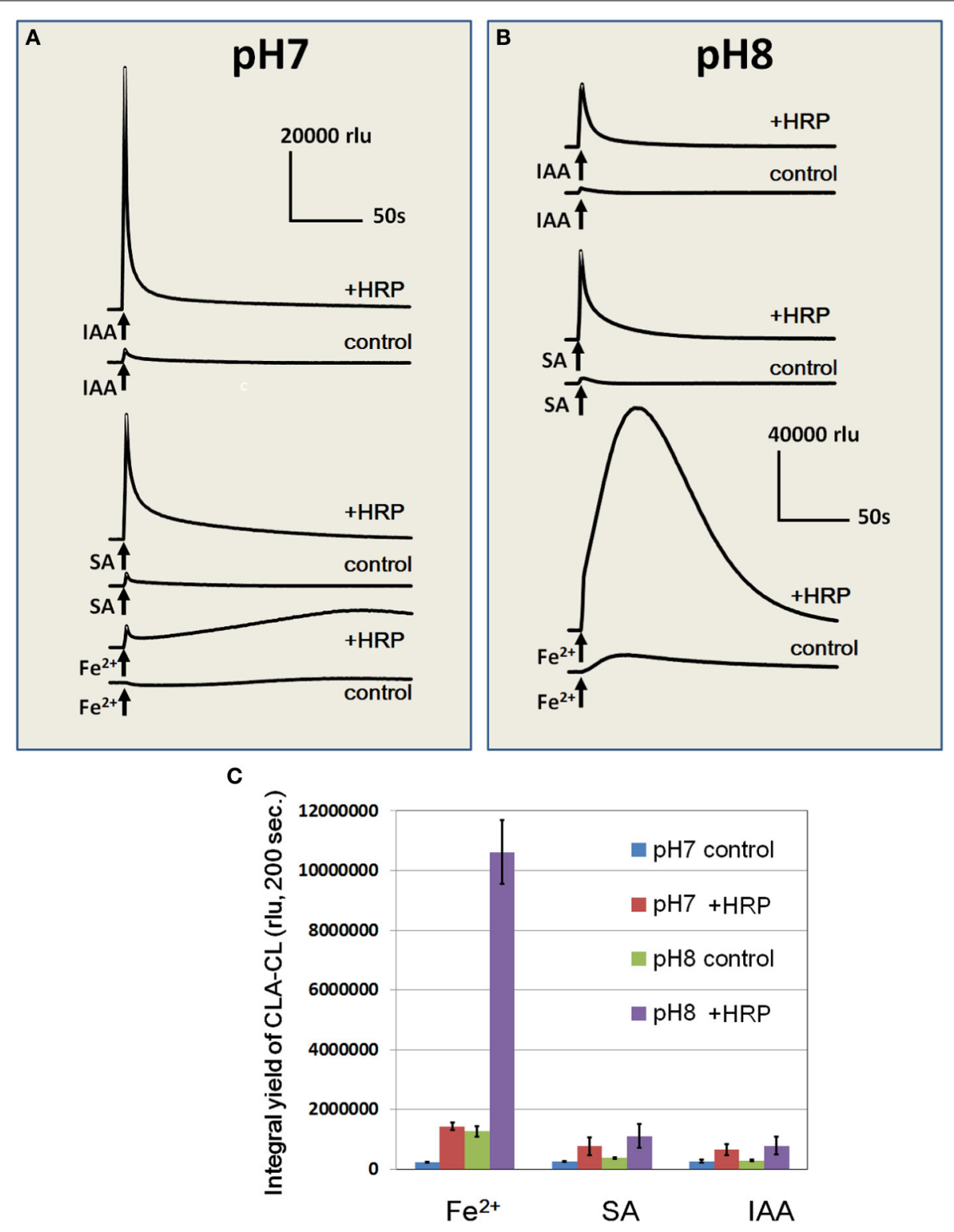

FIGURE 6 | Effects of $\mathrm{Fe}^{2+}$, SA, and IAA on $\mathrm{O}_{2}^{--}$generation in HRP reaction mixture at $\mathbf{p H} \mathbf{7 . 0}$ and 8.0. $\mathrm{Fe}^{2+}, \mathrm{SA}$, or IAA (each $50 \mu \mathrm{M}$ ) was added to control buffer or HRP reaction mixture at $\mathrm{pH} 7.0$ (A) and 8.0 (B)
(C) Integral yields of CLA-CL induced by $\mathrm{Fe}^{2+}, \mathrm{SA}$, and IAA under different $\mathrm{pH}$ were compared. Error bats, SD $(n=3)$. Conditions: total volume, $0.2 \mathrm{ml}$; K-phosphate, $25 \mathrm{mM}$ (pH 7.0 or 8.0); HRP, $1.5 \mu \mathrm{M}$; CLA, $4 \mu \mathrm{M}$. series of steps converting the native POX into ferrous enzyme, and involvement of dissolved oxygen, in order to obtain the CII.

By analogy to NO-responsive events, we attempted to propose a working hypothesis explaining the paths of reactions $\mathrm{Fe}^{2+}$ dependently converting the native POX into CII in the absence of exogenous supplementation of $\mathrm{H}_{2} \mathrm{O}_{2}$ (Figure 1D). Firstly, the $\mathrm{Fe}^{2+}$-mediated conversion of native POX into ferrous enzyme intermediate occurs. Then, this intermediate molecule further reacts with $\mathrm{O}_{2}$ to form catalytically inactive $\mathrm{CIII}$ which readily dissociates and releases $\mathrm{O}_{2}^{--}$and native enzyme. Eventually, CII can be formed through interaction between the native enzyme and $\mathrm{H}_{2} \mathrm{O}_{2}$ which is derived from $\mathrm{O}_{2}^{\bullet-}$. Note that the $\mathrm{O}_{2}^{\bullet-}$-to- $\mathrm{H}_{2} \mathrm{O}_{2}$ conversion can proceed in the presence of hemoproteins and non-heme free iron ions as discussed later.

Our working hypothetic model can be divided into two phases. In the first phase, conversion of native enzyme into ferrous intermediate must be caused so that finally resulting in production of $\mathrm{O}_{2}^{\bullet-}$ upon interaction with molecular oxygen (oxygenation cycle). After completing this cycle, the enzyme must go into further cycles if excess of $\mathrm{Fe}^{2+}$ is present. In the second phase, supply of $\mathrm{H}_{2} \mathrm{O}_{2}$ possibly derived from $\mathrm{O}_{2}^{\bullet-}$ must occur in order to fuel the conventional POX cycle.

Therefore, we have carried out (a) spectroscopic analysis of the fate of native HRP following the addition of $\mathrm{Fe}^{2+}$, 


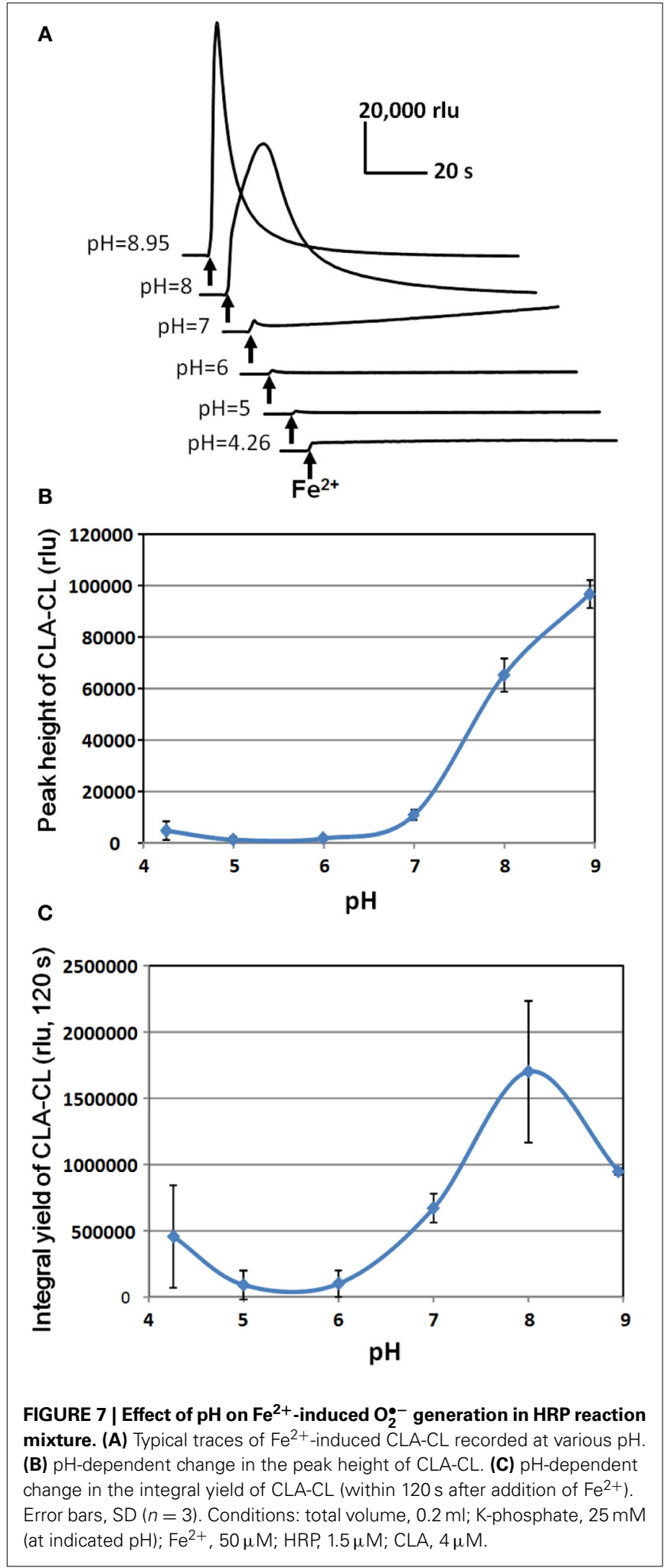

(b) direct measurements of $\mathrm{Fe}^{2+}$-induced oxidative burst represented by generation of $\mathrm{H}_{2} \mathrm{O}_{2}$ and $\mathrm{O}_{2}^{--}$and (c) examinations on the involvement of molecular oxygen in (a) and (b).

\section{POX-CATALYZED ROS PRODUCTION INVOLVING HYDROGEN PEROXIDE}

The formulae shown below originally proposed for describing the mechanism for SA-dependent generation of $\mathrm{O}_{2}^{--}$in plant system (Kawano et al., 1998; Kawano and Muto, 2000) suggest that the byproducts of POX-catalyzed oxidation of phenolics are necessarily involved in generation of $\mathrm{O}_{2}^{\bullet-}$.

$$
\begin{aligned}
\mathrm{POXN}^{(3)}+\mathrm{H}_{2} \mathrm{O}_{2} & \rightarrow \mathrm{CI}^{(5)}+\mathrm{H}_{2} \mathrm{O} \\
\mathrm{CI}^{(5)}+\mathrm{AH} & \rightarrow \mathrm{CII}^{(4)}+\mathrm{A}^{\bullet} \\
\mathrm{CII} & (4)+\mathrm{AH} \\
2 \mathrm{~A}^{\bullet}+2 \mathrm{O}_{2} & \rightarrow 2 \mathrm{~A}^{+}+2 \mathrm{O}_{2}^{\bullet-}
\end{aligned}
$$

POX N stands for native ferric enzyme. $\mathrm{A}^{\bullet}$ and $\mathrm{A}^{+}$are free radical species and the two-electron oxidized intermediate product derived from substrate $\mathrm{AH}$ (such as phenolics or AMAs), respectively. The formal oxidation states of the heme within the enzyme are indicated by numbers in the small brackets. As above, phenolics form a group of $\mathrm{e}^{-}$donating substrates while $\mathrm{H}_{2} \mathrm{O}_{2}$ is viewed as the only $\mathrm{e}^{-}$acceptor. Then, phenoxy radical (shown as $\mathrm{A}^{\bullet}$ ) released thereafter may react with molecular oxygen to form $\mathrm{O}_{2}^{\circ-}$. Since $\mathrm{O}_{2}^{--}$is readily transformed into $\mathrm{H}_{2} \mathrm{O}_{2}$ in biological systems, a single cycle of $\mathrm{AH}$-oxidizing $\mathrm{POX}$ reactions initiated by single unit of $\mathrm{H}_{2} \mathrm{O}_{2}$ results in yield of two units of $\mathrm{O}_{2}^{\bullet-}$ which is equivalent to two units of $\mathrm{H}_{2} \mathrm{O}_{2}$, and therefore, by this way, ROS could be amplified (Kawano, 2003a).

In place of phenolics, AMAs could be used as another group of active substrates (Kawano et al., 2000a,b). Pinontoan and his colleagues have shown that aromatic monoamine-dependent oxidative burst can be widely observed not only in plants but also in yeast cells in vivo (Pinontoan et al., 2002) and pseudo-POX cycle of human hemoglobin (Kawano et al., 2002b).

In case of SA oxidation by plant enzymes, analytical data in support of the production of SA radical species (one of $A^{\bullet}$ ) has been obtained using electron spin resonance spectroscopy by employing a natural spin trapper, ascorbate (Kawano and Muto, 2000). After above studies, the likely structures of the radical and derived cationic intermediate were proposed by Gozzo (2003). In addition, the involvement of CI and CII as the intermediate species required for SA-dependent and AMA-dependent $\mathrm{O}_{2}^{\bullet-}$ generation was spectroscopically confirmed (Kawano et al., 2002c,d).

In plants, the SA-dependently produced $\mathrm{O}_{2}^{--}$acts as a chemical signal required for development of defense mechanism against pathogenic microbes (Kawano et al., 1998) and closure of stomata on leaves (Mori et al., 2001; Khokon et al., 2011). In model plant cells, TPC1 calcium-permeable cation channel is a likely target of the SA signal transduction pathway mediated with $\mathrm{O}_{2}^{\bullet-}$ (Lin et al., 2005).

\section{$\mathrm{H}_{2} \mathrm{O}_{2}$-INDEPENDENT ROS PRODUCTION CATALYZED BY IAA-STIMULATED POXs}

Metabolism of IAA is common interest to many plant biologists. Through oxidation of IAA via two different mechanisms, it has been considered that plant POXs are involved in the metabolism of IAA. One mechanism involves the conventional 
$\mathrm{H}_{2} \mathrm{O}_{2}$-dependent pathway and the other requires the incorporation of molecular oxygen $\left(\mathrm{O}_{2}\right)$ but not of $\mathrm{H}_{2} \mathrm{O}_{2}$ (Gazaryan et al., 1996; Savitsky et al., 1999; Kawano et al., 2001). The conventional POX cycle for the oxidation of various substrates coupled to the consumption of $\mathrm{H}_{2} \mathrm{O}_{2}$ proceeds as follows:

$$
\begin{aligned}
\mathrm{POXN}^{(3)}+\mathrm{H}_{2} \mathrm{O}_{2} & \rightarrow \mathrm{CI}^{(5)}+\mathrm{H}_{2} \mathrm{O} \\
\mathrm{CI}^{(5)}+\mathrm{S} & \rightarrow \mathrm{CII}^{(4)}+\mathrm{P} \\
\mathrm{CII}^{(4)}+\mathrm{S}+\mathrm{H}^{+} & \rightarrow \text { POX N }^{(3)}+\mathrm{H}_{2} \mathrm{O}+\mathrm{P}
\end{aligned}
$$

where $\mathrm{S}$ and $\mathrm{P}$ are the substrate and product of its one-electron oxidation, respectively (Kawano, 2003a).

IAA can be oxidized by a wide variety of plant POXs, as model has been proposed through the study using HRP focusing on the conventional $\mathrm{H}_{2} \mathrm{O}_{2}$-dependent reactions with no strict substrate specificity (Kawano, 2003a). It is noteworthy that most plant POXs including HRP oxidize IAA also via an alternative $\mathrm{H}_{2} \mathrm{O}_{2}$-independent pathway requiring $\mathrm{O}_{2}$ (Smith et al., 1982). Reportedly, unlike animal and microbial POXs, most members of plant POXs are considered to behave as highly specific IAA oxygenases by sharing the domains required for binding of auxin (Gazaryan et al., 1996). The proposed $\mathrm{H}_{2} \mathrm{O}_{2}$-independent cycle for IAA oxidation involves the formation of a ternary complex, enzyme-IAA-dioxygen (Savitsky et al., 1999), finally yielding IAA cation radicals and $\mathrm{O}_{2}^{\bullet-}$ as by-products as follows (Kawano et al., 2001):

$$
\begin{aligned}
\text { POX }+ \text { IAA } & \leftrightarrow[\text { POX-IAA }] \\
{[\text { POX-IAA }]+\mathrm{O}_{2} } & \leftrightarrow[\text { POX-IAA-O }] \\
{[\text { POX-IAA-O }] } & \rightarrow \text { POX }+ \text { IAA }^{+}+\mathrm{O}_{2}^{\bullet-}
\end{aligned}
$$

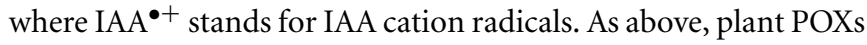
can catalyze the IAA-dependent generation of $\mathrm{O}_{2}^{\bullet-}$ in the absence of $\mathrm{H}_{2} \mathrm{O}_{2}$. However, depending on the concentrations of ROS and IAA, plant enzymes are readily inactivated and degraded by forming P-670 pigment which is an irreversibly inactivated form (Kawano et al., 2002a).

Based on the views that formation of enzyme-substrate complexes such as [POX-IAA- $\mathrm{O}_{2}$ ] results in release of $\mathrm{O}_{2}^{\bullet-}$ (Kawano et al., 2001), medical application of HRP-labeled antibodies and IAA has been proposed as a novel $\mathrm{O}_{2}^{\bullet-}$-generating system for cancer cell-targeted and controlled cell death induction, by designing the HRP-conjugated immuno-labeling of cancerrelated molecules or expression of recombinant HRP in mammalian cells (Folkes and Wardman, 2001; Folkes et al., 2002; Kawano, 2003b; Dai et al., 2012). Although the IAA-induced $\mathrm{O}_{2}^{\bullet-}$ in HRP reaction mixture is very intense, the IAA-induced oxidative burst likely lasts only for few seconds (Kawano et al., 2001). This is largely due to the fact that IAA behaves as a suicide substrate for plant POXs, in its excess, irreversibly converting the oxygen-dependently formed CIII into inactivated verdohemoprotein (P-670) (Kawano et al., 2002a). In this point of view, induction of robust and long-lasting oxidative burst by application of $\mathrm{Fe}^{2+}$ may expand the possible applications of plant POXs for medical purposes.

\section{POSSIBLE ROLES FOR FERROUS POX INTERMEDIATE AND CIII}

As reviewed elsewhere, the conventional POX cycle involves the formation of CI in which the localization of second radical could be on the heme or on amino acid residues around the heme pocket depending on the nature of protein species (Kawano, 2003a,b). This variation may largely contribute to determination of the types of reaction catalyzed by hemoproteins. On the other hand, we have previously proposed the hypothetical reactions in the oxygenation cycle of plant POXs (Figure 1A) which can be solely attributed to the chemistry of heme, by analogy to the behaviors of other hemoproteins such as hemoglobin (Kawano et al., 2004).

CIII is the temporally inactive POX intermediate (heme$\mathrm{Fe}^{\mathrm{II}}-\mathrm{O}_{2}$ ) which is analogous to oxygen-bound hemoglobin which is readily auto-oxidized and decomposed into $\mathrm{O}_{2}^{\bullet-}$ and met-hemoglobin (Arayash, 1999; Kawano et al., 2002b). Note that met-hemoglobin is a ferric protein analogous to the native ferric POX and interestingly, pseudo-peroxidase catalytic activity can be found in met-hemoglobin (Kawano et al., 2002b).

When the heme-oxygen complex in CIII of plant POX dissociates, $\mathrm{O}_{2}^{\bullet-}$ and the native enzyme are released. Many of heme proteins, such as POX from French bean, are capable of generating $\mathrm{H}_{2} \mathrm{O}_{2}$ (derived from $\mathrm{O}_{2}^{\bullet-}$ ) at higher $\mathrm{pH}$ by a mechanism that involves the formation of CIII (Bolwell et al., 2002), thus distinct from the conventional POX reactionmediated oxidative burst as such involving SA (Kawano et al., 1998).

The most likely mechanism considered to form CIII is the direct conversion of ferric proteins into CIII via single step in the presence of $\mathrm{O}_{2}^{\bullet-}$ : heme-Fe ${ }^{\mathrm{III}}+\mathrm{O}_{2}^{\bullet-} \rightarrow$ heme-Fe ${ }^{\mathrm{II}}-\mathrm{O}_{2}$ or heme$\mathrm{Fe}^{\mathrm{III}}-\mathrm{O}_{2}^{\bullet-}$ (Arayash, 1999). However, this model fails to explain the burst of $\mathrm{O}_{2}^{\bullet-}$ often observed in plant POX model (Bolwell et al., 1998, 2002).

The missing link in the oxygenation cycle of ROS production involving CIII is the mechanism for reduction of native ferric POX (heme-Fe ${ }^{\mathrm{III}}$ ) to ferrous enzyme (heme-Fe ${ }^{\mathrm{II}}$ ). It is tempting to hypothesize that $\mathrm{pH}$-dependent CIII-mediated ROS production requires the formation of CIII via preceding formation of ferrous enzyme, thereafter allowing spontaneous oxygenation into CIII (heme-Fe $\mathrm{F}^{\mathrm{II}}+\mathrm{O}_{2} \rightarrow$ heme-Fe ${ }^{\mathrm{II}}-\mathrm{O}_{2}$ ) as predicted earlier (Kawano et al., 2004). Therefore, apparently, the formation of ferrous enzyme from native POX would be an important step for supporting the oxidative burst involving CIII.

It is well documented that extracellular alkalization occurs in plant tissues upon attacked by pathogens or treatments with elicitors, eventually allowing the $\mathrm{pH}$-dependent extracellular POXmediated oxidative burst at the site of microbial challenges (Bolwell et al., 1998). Here, we would like to propose a likely role for free ferrous ion in reduction of ferric POX into ferrous enzyme which readily produces $\mathrm{O}_{2}^{\bullet-}$ via mechanism involving CIII, especially under alkaline condition possibly contributing to the plant defense mechanism.

In conclusion, the present study proposed that plant POXcatalyzed production of $\mathrm{O}_{2}^{\bullet-}$ can be stimulated in the absence of conventional POX substrates but in the presence free $\mathrm{Fe}^{2+}$ through following reactions (Figure 1D): 


$$
\begin{aligned}
\operatorname{POX~N}^{(3)}+\mathrm{Fe}^{2+} & \leftrightarrow \text { ferrous-POX } \\
\text { ferrous-POX }^{(2)}+\mathrm{O}_{2} & \leftrightarrow \mathrm{Fe}^{3+} \\
\mathrm{CIII}^{(6)} & \leftrightarrow \mathrm{POXN}^{(3)}+\mathrm{O}_{2}^{\bullet-}
\end{aligned}
$$

We view here that the recorded $\mathrm{H}_{2} \mathrm{O}_{2}$ could be derived from $\mathrm{O}_{2}^{\bullet-}$. Recent study provided us a notation that iron peroxide species have been identified as important intermediates in a number of nonheme iron as well as heme-containing enzymes (Namuswe et al., 2008). Therefore, by analogy, we could possibly expect that ferrous intermediate of plant POXs also interact with $\mathrm{O}_{2}^{\bullet-}$ to yield $\mathrm{H}_{2} \mathrm{O}_{2}$ in a manner similar to bacterial superoxide reductase. Or, excess of $\mathrm{Fe}^{2+} / \mathrm{Fe}^{3+}$ unbound to enzymes also non-enzymatically catalyses the disproportionation of $\mathrm{O}_{2}^{\bullet-}$ into $\mathrm{H}_{2} \mathrm{O}_{2}$.

Eventually, resultant $\mathrm{H}_{2} \mathrm{O}_{2}$ may contribute to conversion of native POX to CII via CI as previously demonstrated (Kawano et al., 2002c,d) (Figure 1D). Conversion of native POX to CII in the absence of initial supply of $\mathrm{H}_{2} \mathrm{O}_{2}$ reportedly occurs by treating soybean POX with NO (Takayama et al., 2012). Since NO converts some heme enzymes such as catalase into CIII (unpublished results), the mechanisms undermined should be similar to the case of $\mathrm{Fe}^{2+}$-induced redox changes in HRP.

\section{ACKNOWLEDGMENT}

Tomonori Kawano was supported by a grant of Regional Innovation Strategy Support Program implemented by Ministry of Education, Culture, Sports, Science and Technology (MEXT), Japan.

\section{REFERENCES}

Arayash, A. I. (1999). Hemoglobin-based blood substitutes: oxygen carriers, pressor agents, or oxidants? Nat. Biotechnol. 17, 545-549. doi: 10.1038/9849

Bindschedler, L. V., Dewdney, J., Blee, K. A., Stone, J. M., Asai, T., Plotnikov, J., et al. (2006). Peroxidase-dependent apoplastic oxidative burst in Arabidopsis required for pathogen resistance. Plant J. 47, 851-863. doi: 10.1111/j.1365313X.2006.02837.x

Bolwell, G. P., Bindschedler, L. V., Blee, K. A., Butt, V. S., Davies, D. R., Gardner, S. L., et al. (2002). The apoplastic oxidative burst in response to biotic stress in plants: a three-component system. J. Exp. Bot. 53, 1367-1376. doi: 10.1093/jexbot/53.372.1367

Bolwell, G. P., Davies, D. R., Gerrish, C., Auh, C. K., and Murphy, T. M. (1998). Comparative biochemistry of the oxidative burst produced by rose and French bean cells reveals two distinct mechanisms. Plant Physiol. 116, 1370-1385. doi: 10.1104/pp.116.4.1379

Dai, M., Liu. J., Chen, D.-E., Rao, D.-E., Tang, Z.-J., Ho, W.-Z., et al. (2012). Tumortargeted gene therapy using Adv-AFP-HRPC/IAA prodrug system suppresses growth of hepatoma xenografted in mice. Cancer Gene Ther. 19, 77-83. doi: $10.1038 /$ cgt.2011.65

Folkes, L. K., Greco, O., Dachs, G. U., Stratfoed, M. R. L., and Wardman. P. (2002). 5-Fluoroindole-3-acetic acid:a prodrug activated by a peroxidase with potential for use in targeted cancer therapy. Biochem. Pharmacol. 63, 265-272. doi: 10.1016/S0006-2952(01)00868-1

Folkes, L. K., and Wardman, P. (2001). Oxidative activation of indole-3-acetic to cytotoxic species apotential new role for plant auxins in cancer therapy. Biochem. Pharmacol. 61, 129-136. doi: 10.1016/S0006-2952(00)00498-6

Gazarian, I. G., and Lagrimini, L. M. (1998). Anaerobic stopped-flow studies of indole-3-acetic acid oxidation by dioxygen catalyzed by horseradish peroxidase $\mathrm{C}$ and anionic tobacco peroxidase at neutral pH: catalase effect. Biophys. Chem. 72, 231-237. doi: 10.1016/S0301-4622(98)00098-2

Gazaryan, I. G., Lagrimini, L. M., Ashby, G. A., and Thorneley, N. F. (1996). Mechanism of indole-3-acetic acid oxidation by plant peroxidases: anaerobic stopped-flow spectrophotometric studies on horseradish and tobacco peroxidases. Biochem. J. 313, 841-847.
Gozzo, F. (2003). Systemic acquired resistance in crop protection: from nature to a chemical approach. J. Agric. Food Chem. 51, 4487-4503. doi: 10.1021/jf030025s

Hiraga, S., Sasaki, K., Ito, H., Ohashi, Y., and Matsui, H. (2001). A large family of class III plant peroxidases. Plant Cell Physiol. 42, 462-468. doi: $10.1093 / \mathrm{pcp} / \mathrm{pce} 061$

Kawano, T. (2003a). Roles of the reactive oxygen species-generating peroxidase reactions in plant defense and growth induction. Plant Cell Rep. 21, 829-837. doi: 10.1007/s00299-003-0591-z

Kawano, T. (2003b). Possible use of indole-3-acetic acid and its antagonist tryptophan betaine in controlled killing of horseradish peroxidase-labeled human cells. Med. Hypotheses 60, 664-666. doi: 10.1016/S0306-9877(03)00012-4

Kawano, T., and Bouteau, F. (2013). Crosstalk between intracellular and extracellular salicylic acid signaling events leading to long-distance spread of signals. Plant Cell Rep. 32, 1125-1138. doi: 10.1007/s00299-013-1451-0

Kawano, T., Furuichi, T., and Muto, S. (2004). Controlled free salicylic acid levels and corresponding signaling mechanisms in plants. Plant Biotechnol. 21, 319-335. doi: 10.5511/plantbiotechnology.21.319

Kawano, T., Kawano, N., Hosoya, H., and Lapeyrie, F. (2001). Fungal auxin antagonist hypaphorine competitively inhibits indole-3-acetic acid-dependent superoxide generation by horseradish peroxidase. Biochem. Biophys. Res. Commun. 288, 546-551. doi: 10.1006/bbrc.2001.5800

Kawano, T., Kawano, N., and Lapeyrie, F. (2002a). A fungal auxin antagonist, hypaphorine prevents the indole-3-acetic aciddependent irreversible inactivation of horseradish peroxidase: inhibition of Compound III-mediated formation of P-670. Biochem. Biophys. Res. Commun. 294, 553-559. doi: 10.1016/S0006291X(02)00513-2

Kawano, T., and Muto, S. (2000). Mechanism of peroxidase actions for salicylic acid-induced generation of active oxygen species and an increase in cytosolic calcium in tobacco suspension culture. J. Exp. Bot. 51, 685-693. doi: 10.1093/jexbot/51.345.685

Kawano, T., Muto, S., Adachi, M., Hosoya, H., and Lapeyrie, F. (2002c). Spectroscopic evidence in support of horseradish peroxidase Compound IIcatalyzed oxidation of salicylic acid but not of phenylethylamine. Biosci. Biotechnol. Biochem. 66, 651-654. doi: 10.1271/bbb.66.651

Kawano, T., Muto, S., Adachi, M., Hosoya, H., and Lapeyrie, F. (2002d). Spectroscopic evidence that salicylic acid converts a temporal inactive form of horseradish peroxidase (Compound III) to the irreversibly inactivated verdohemoprotein (P-670). Biosci. Biotechnol. Biochem. 66, 646-650. doi: 10.1271/bbb.66.646

Kawano, T., Pinontoan, R., Hosoya, H., and Muto, S. (2002b). Monoaminedependent production of reactive oxygen species catalyzed by pseudoperoxidase activity of human hemoglobin. Biosci. Biotechnol. Biochem. 66, 1224-1232. doi: 10.1271/bbb.66.1224

Kawano, T., Pinontoan, R., Uozumi, N., Miyake, C., Asada K., Kolattukudy, P. E., et al. (2000a). Aromatic monoamine-induced immediate oxidative burst leading to an increase in cytosolic $\mathrm{Ca}^{2+}$ concentration in tobacco suspension culture. Plant Cell Physiol. 41:1251-1258. doi: 10.1093/pcp/pcd052

Kawano, T., Pinontoan, R., Uozumi, N., Morimitsu, Y., Miyake, C., Asada, K., et al. (2000b). Phenylethylamine-induced generation of reactive oxygen species and ascorbate free radicals in tobacco suspension culture: mechanism for oxidative burst mediating $\mathrm{Ca}^{2+}$ influx. Plant Cell Physiol. 41, 1259-1266. doi: $10.1093 / \mathrm{pcp} / \mathrm{pcd} 053$

Kawano, T., Sahashi, N., Takahashi, K., Uozumi, N., and Muto, S. (1998). Salicylic acid induces extracellular superoxide generation followed by an increase in cytosolic calcium ion in tobacco suspension culture: the earliest events in salicylic acid signal transduction. Plant Cell Physiol. 39, 721-730. doi: 10.1093/oxfordjournals.pcp.a029426

Khokon, M. A. R., Okuma, E., Hossain, M. A., Munemasa, S., Uraji, M., Nakamura, Y., et al. (2011). Involvement of extracellular oxidative burst in salicylic acidinduced stomatal closure in Arabidopsis. Plant Cell Environ. 34, 434-443. doi: 10.1111/j.1365-3040.2010.02253.x

Lin, C., Yu, Y., Kadono, T., Iwata, M., Umemura, K., Furuichi, T., et al. (2005). Action of aluminum, novel TPC1-type channel inhibitor, against salicylateinduced and cold shock-induced calcium influx in tobacco BY-2 cells. Biochem. Biophys. Res. Commun. 332, 823-830. doi: 10.1016/j.bbrc.2005.05.030

Monetti, E., Kadono, T., Tran, D., Azzarello, E., Arbelet-Bonnin, D., Biligui, B., et al. (2014). Deciphering in early events involved in hyperosmotic stress-induced programmed cell death in tobacco BY-2 cells. J. Exp. Bot 65, 1361-1375. doi: $10.1093 /$ jxb/ert460 
Mori, I. C., Pinontoan, R., Kawano, T., and Muto, S. (2001). Involvement of superoxide generation in salicylic acid-induced stomatal closure in Vicia faba. Plant Cell Physiol. 42, 1383-1388. doi: 10.1093/pcp/pce176

Namuswe, F., Kasper, G. D., Narducci Sarjeant, A. A., Hayashi, T., Krest, C. M., Green, M. T., et al. (2008). Rational tuning of the thiolate donor in model complexes of superoxide reductase: direct evidence for a trans influence in Fe ${ }^{\mathrm{III}}$-OOR complexes. J. Am. Chem. Soc. 130, 14189-14200. doi: 10.1021/ja8 031828

O’Brien, J. A., Daudi, A., Butt, V. S., and Bolwell, G. P. (2012b). Reactive oxygen species and their role in plant defence and cell wall metabolism. Planta 236, 765-779. doi: 10.1007/s00425-012-1696-9

O'Brien, J. A., Daudi, A., Finch, P., Butt, V. S., Whitelegge, J. P., Souda, P., et al. (2012a). A peroxidase-dependent apoplastic oxidative burst in cultured Arabidopsis cells functions in MAMP-elicited defense. Plant Physiol. 158, 2013-2027. doi: 10.1104/pp.111.190140

Passardi, F., Cosio, C., Penel, C., and Dunand, C. (2005). Peroxidases have more functions than a Swiss army knife. Plant Cell Rep. 24, 255-265. doi: 10.1007/s00299-005-0972-6

Penel, C. (2000). “The peroxidase system in higher plants," in Integrated Plant Systems, eds H. Greppin, C. Penel, W. J. Broughton, and R. Strasser (Geneva: University of Geneva), 359-367.

Perazzolli, M., Dominici, P., Romero-Puertas, M. C., Zago, E., Zeier, J., Sonoda, M., et al. (2004). Arabidopsis nonsymbiotic hemoglobin Ahbl modulates nitric oxide bioactivity. Plant Cell 16, 2785-2794. doi: 10.1105/tpc.104. 025379

Pinontoan, R., Krystofava, S., Kawano, T., Mori, I. C., Tsuji, F., Iida, H., et al. (2002). Phenylethylamine induces an increase in cytosolic $\mathrm{Ca}^{2+}$ in yeast. Biosci. Biotechnol. Biochem. 66, 1069-1074. doi: 10.1271/bbb.66.1069

Savitsky, P. A., Gazaryan, I. G., Tishkov, V. I., Lagrimini, L. M., RuzGas, T., and Gorton, L. (1999). Oxidation of indole-3-acetic acid by dioxygen catalyzed by plant peroxidases: specificity for the enzyme structure. Biochem. J. 340, 579-583. doi: 10.1042/0264-6021:3400579

Smith, A. M., Morrison, W. L., and Milham, P. J. (1982). Oxidation of indole3-acetic acid by peroxidase: involvement of reduced peroxidase and compound III with superoxide as a product. Biochemistry 21, 4414-4419. doi: 10.1021/bi00261a034

Takayama, A., Kadono, T., and Kawano, T. (2012). Heme redox cycling in soybean peroxidase: hypothetical model and supportive data. Sens. Mater. 24, 87-97.

Yoshioka, H., Bouteau, F., and Kawano, T. (2008). Discovery of oxidative burst in the field of plant immunity: looking back at the early pioneering works and towards the future development. Plant Signal. Behav. 3, 153-155. doi: $10.4161 /$ psb.3.3.5537

Conflict of Interest Statement: The authors declare that the research was conducted in the absence of any commercial or financial relationships that could be construed as a potential conflict of interest.

Received: 19 February 2014; accepted: 02 June 2014; published online: 01 July 2014

Citation: Kimura M, Umemoto $Y$ and Kawano T (2014) Hydrogen peroxideindependent generation of superoxide by plant peroxidase: hypotheses and supportive data employing ferrous ion as a model stimulus. Front. Plant Sci. 5:285. doi: 10.3389/ fpls.2014.00285

This article was submitted to Plant Physiology, a section of the journal Frontiers in Plant Science.

Copyright (c) 2014 Kimura, Umemoto and Kawano. This is an open-access article distributed under the terms of the Creative Commons Attribution License (CC BY). The use, distribution or reproduction in other forums is permitted, provided the original author(s) or licensor are credited and that the original publication in this journal is cited, in accordance with accepted academic practice. No use, distribution or reproduction is permitted which does not comply with these terms. 